\title{
Astrid Hovden, Between Village and Monastery. A Historical Ethnography of a Tibetan Buddhist Community in North-Western Nepal
}

\section{(2) OpenEdition}

\section{Journals}

Electronic version

URL: https://journals.openedition.org/emscat/2963

DOI: $10.4000 /$ emscat.2963

ISSN: 2101-0013

Publisher

Centre d'Etudes Mongoles \& Sibériennes / École Pratique des Hautes Études

Electronic reference

"Astrid Hovden, Between Village and Monastery. A Historical Ethnography of a Tibetan Buddhist Community in North-Western Nepal", Études mongoles et sibériennes, centrasiatiques et tibétaines [Online], 48 | 2017, Online since 05 December 2017, connection on 13 July 2021. URL: http:// journals.openedition.org/emscat/2963; DOI: https://doi.org/10.4000/emscat.2963

This text was automatically generated on 13 July 2021.

(c) Tous droits réservés 


\section{Astrid Hovden, Between Village and Monastery. A Historical Ethnography of a Tibetan Buddhist Community in North-Western Nepal}

\section{REFERENCES}

$\mathrm{PhD}$ thesis, defended on $18^{\text {th }}$ March 2016 at the University of Oslo. Committee:

U. Roesler (opponent), P. Schwieger (opponent), M. Teeuwen (committee administrator), H. Havnevik (supervisor), C. Ramble (co-supervisor)

1 The objective of the thesis is to investigate the multifaceted relationship between the religious and secular institutions in Limi (Sle mi), a community consisting of three villages and monasteries located in Nepal's Humla district, just south of the border with Tibet. Analytically, the thesis revolves around four interrelated themes, which are explored both diachronically and synchronically: social organisation, decision-making, monastic recruitment and patronage. While keeping the main focus on local agency, the thesis discusses how these domains have been developed, maintained and changed in the context of broader socio-economic, religious, and political transformation processes in the region.

2 Methodologically, the thesis is based on a coupling of a predominantly ethnographic approach with selective reading of historical texts and philological analysis of administrative documents from the local village and monastery archive. Most of the material has been collected through 12 months of classical ethnographic fieldwork in the three villages in Limi from 2010-2012. In addition, shorter stints of fieldwork were conducted in the district headquarter Simikot and in Kathmandu, where a sizeable part of the community is temporarily or permanently settled. The fieldwork involved semistructured, open, and informal interviews with monks and laity, household surveys and mapping, as well as participant observation. The thesis is written as a historical 
ethnography, and historical lines are drawn back to the turn of the millennium, but most of the chapters focus on events from the end of the $19^{\text {th }}$ century and until today.

After a presentation of the material and discussion of methodological and ethical challenges, the first part of the thesis documents the history of the community from the establishment of the first settlement over a millennium ago and until the end of the $20^{\text {th }}$ century. Exploring the community's relationship to shifting regional state formations, the thesis discusses how the history of the monasteries and villages has been shaped by its location in a frontier region.

Two claims found in local documents are given particular attention: that the Vairocana temple in the Rinchenling (Rin chen gling) monastery in Waltse (dBal rtse) was founded by the translator Rinchen Zangpo (Rin chen bZang po, 958-1055) at the dawn of the $10^{\text {th }}$ century, and that he passed away in Limi. Although it will be impossible to determine the identity of the founder, the thesis argues that religiously, stylistically, and historically the temple conforms to Rinchen Zangpo's heritage. The second claim, that Rinzhen Zangpo passed away from a hermitage in Limi, is in fact also mentioned but refuted - in his biography, and is probably unfounded. But, as attested in both the translator's biography and a $13^{\text {th }}$ century biography of Drigung Kagyu ('Bri gung bKa' brgyud) lamas, he meditated in Limi towards the end of his life, most likely in the hermitage at Chaye (sPya ye) ${ }^{1}$.

This hermitage was expanded by one of the main Drigung Kagyu lamas in the $13^{\text {th }}$ century. In the same period, the Drigungpas established two other temples in Limi, which were secured support by king Krācalla of Jumla and subsequently developed into small monasteries. In the aftermath of dramatic events in the $17^{\text {th }}$ century, the three monasteries in the valley merged with Rinchenling. The monastery was gradually expanded and from the end of the $19^{\text {th }}$ century onwards, monk levy and an associated sponsorship duty were introduced to ensure a stable supply of monk recruits and funding.

6 This monastic recruitment and patronage system is dependent on a particular type of economy and household organisation. The next part of the thesis presents an outline of social organisation and local livelihoods, and discusses how being born - or married into - a household governs the villagers' access to land and other communal resources, participation in decision-making, level of taxation, and various types of responsibilities to the monastery. My analysis of the population and residence pattern shows that the demographic trends in Limi largely conform to comparable communities in other parts of the Nepal Himalayas. Since the end of the 1990s, there has been an increasing outmigration for the purpose of lay and monastic education as well as business. Outmigration is, however, restricted by rigorous implementation of the system for monastic recruitment and other village obligations, but this system is increasingly experienced as being out of step with the rest of the world, and has recently been challenged by the younger generation.

7 Since the middle of the $20^{\text {th }}$ century with the downfall of the Ranas and the introduction of the Panchayat system the traditional forms of hereditary village leadership in the Tibetan speaking communities of Nepal have been in a process of transition. The thesis discusses how a combination of local and national political and socioeconomic factors has contributed to the development of a hybrid village management system in Limi. The communities have retained the main features of the traditional management system, but the village government has become more 
democratic, and the last few years have seen an increasing integration with the Nepali political administration.

8 Although the villages and monasteries are governed by separate administrations, there are a number of areas of mutual influence between them. One of the most salient areas of interaction is that of monastic funding and recruitment. Taxation has been a frequently neglected topic in studies of Tibetan communities, but has constituted an important source for funding both for secular and monastic institutions. The thesis seeks to contribute to the filling of this gap in our knowledge, and investigates the role of the tax system in Limi, which consists partly of local adaptations of former external taxes (phyi khral) to Tibet and Nepal, and partly of internal taxes (nang khral) to the village and the monastery. Translation of the fiscal terminology is not straightforward, and it is not always obvious where to draw the line between taxes and other community obligations; many of the internal taxes can probably best be understood as religious donations that have gradually solidified into a compulsory tax. Both village and monastic taxes are paid largely in kind and include lease fees for fields, taxes on private property, ritual expenses and allowances, various types of corvée, as well as monastic recruitment.

Recruitment by conscription, or monk levy (grwa khral) has been referred to as one of the traditional ways of monastic recruitment in Tibetan societies, but the fact that sending the second son to the monastery has been a frequently stated norm does not necessarily mean that it has been enforced. The practice has hardly been subject to detailed analysis and has therefore been poorly understood. A review of the historical literature of Ngari (mNga' ris) shows that the monk levy has been practised at least in a number of monasteries in Guge (Gu ge) and Purang (sPu hreng). In Ngari the practice seems to have been instigated by the Ganden Phodrang (dGa' ldan Pho brang) government in an effort to control and strengthen the monasteries in the region, whereas in Limi the monk levy was instituted in 1896 during the visit of the thirty-third Drigung hierarch. The recruitment contract (gan rgya), which is translated and analysed in the thesis, describes the immediate circumstances leading up to the establishment, the authorities involved, and the conditions for the rule, as well as fines for breaking it. The thesis then examines the ways in which the system of monk levy and other forms of monastic recruitment have been implemented and discusses some of its implications for monastic life and social organisation in the three villages. The levy has been variously endorsed and challenged, and since the split of the monasteries in the 1980s the assemblies in the respective villages have chosen different solutions on how to implement the rule.

10 The final chapter is devoted to the monastic economy. Many Tibetan Buddhist monasteries have been landowners, but the size of their landholdings has varied considerably and so has the relative importance of land tax for the monastic coffers. The thesis investigates how the local monasteries in Limi are funded through a combination of five main types of income: through monastery and village taxes, capital investments, rotational sponsorship, external support as well as voluntary patronage. Despite of the many obligations, the villagers make a substantial number of voluntary donations to the monastery. Some of these are commitments made by the forebears of the current householders, but most are one time donations according to the villagers' wishes and needs. 
11 The local system of monastic patronage has occasionally been challenged, and the last decades have seen two major reforms to reduce the costs of rituals and to make the sponsorship system more aligned with current norms of justice. However, in the long run, such reforms may not be sufficient to maintain the old system for village and monastery management, recruitment and patronage. The concluding chapter sketches a picture not only of how these social institutions and mechanisms are interconnected, but also of the increasingly felt tension between them, epitomised in an epilogue about recent events in Limi.

\section{BIBLIOGRAPHY}

rDo rje mdzes 'od/Don mo ri pa [13 ${ }^{\text {th }}$ century] 1985 bKa' brgyud kyi rnam thar chen mo rin po che' $i$ gter mdzod dgos 'dod 'byung gnas (Bir, Kangra H.P., D. Tsondu Senghe), TBRC no. 27600.

\section{NOTES}

1. bKa' brgyud kyi rnam thar chen mo rin po che'i gter mdzod dgos 'dod 'byung gnas, written by rDo rje mdzes 'od/Don mo ri pa (1 $3^{\text {th }}$ century). Copy reproduced from a rare manuscript from Dzang Phelgyeling in Limi. Published by D. Tsondu Senghe in 1985. 